\section{Changes in 'Riviera' Bermudagrass [Cynodon dactylon (L.) Pers.] Carotenoid Pigments after Treatment with Three $p$-Hydroxyphenylpyruvate Dioxygenase-inhibiting Herbicides}

\author{
James T. Brosnan', Dean A. Kopsell, Matthew T. EImore, \\ Gregory K. Breeden, and Gregory R. Armel \\ Department of Plant Sciences, University of Tennessee, 252 Ellington Plant \\ Sciences Building, Knoxville, TN 37996-4561
}

Additional index words. efficacy, turfgrass management, carotenoids, lutein, weed control, xanthophyll cycle, zeaxanthin

\begin{abstract}
Mesotrione, topramezone, and tembotrione are inhibitors of the enzyme $p$ hydroxyphenylpyruvate dioxygenase (HPPD), which impacts the carotenoid biosynthetic pathway. An experiment was conducted to determine the effects of mesotrione, topramezone, and tembotrione on carotenoid pigment concentrations in common bermudagrass [Cynodon dactylon (L.) Pers.; cv. Riviera] leaf tissues. Bermudagrass plants were treated with three rates of mesotrione $\left(0.28,0.35\right.$, and $\left.0.42 \mathrm{~kg} \cdot \mathrm{ha}^{-1}\right)$, topramezone $(0.018$, 0.025 , and $\left.0.038 \mathrm{~kg} \cdot \mathrm{ha}^{-1}\right)$, and tembotrione $\left(0.092,0.184\right.$, and $\left.0.276 \mathrm{~kg} \cdot \mathrm{ha}^{-1}\right)$. The lowest rate of each herbicide represented the maximum labeled use rate for a single application. Percent visual bleaching was measured at 3, 7, 14, 21, 28, and 35 days after application (DAA). Leaf tissues were sampled on the same dates and assayed for carotenoids. Topramezone and tembotrione bleached bermudagrass leaf tissues to a greater degree than mesotrione. Concomitantly, topramezone and tembotrione also reduced total chlorophyll (chlorophyll $\boldsymbol{a}+\boldsymbol{b}$ ), $\boldsymbol{\beta}$-carotene, lutein, and total xanthophyll cycle pigment concentrations (zeaxanthin + antheraxanthin + violaxanthin) more than mesotrione. Increases in visual bleaching resulting from application rate were accompanied by linear reductions in lutein, $\beta$-carotene, and violaxanthin for all herbicides. Topramezone and tembotrione increased the percentage of zeaxanthin + antheraxanthin in the total xanthophyll pigment pool (ZA/ZAV) 7 days after peak visual bleaching was observed at 14 DAA. Reductions in ZA/ZAV were reported after 21 DAA. This response indicates that sequential applications of topramezone and tembotrione should be applied on 14- to 21-day intervals, because stress induced by these herbicides is greatest at these timings. Increases in photoprotective xanthophyll cycle pigments (ZA/ZAV) at 14 to 21 DAA may be a mechanism allowing bermudagrass to recover from HPPD-inhibiting herbicide injury, because bermudagrass recovered from all treatments by 35 DAA. Data in the current study will allow turf managers to design physiologically validated bermudagrass control programs with HPPD-inhibiting herbicides. Chemical names: mesotrione [2-(4methysulfonyl-2-nitrobenzoyl)-1,3-cyclohexanedione], tembotrione \{2-[2-chloro-4-(methylsulfonyl)-3-[(2,2,2-(trifluoroethoxy)methyl]benzoyl]-1,3-cyclohexanedione, , topramezone \{[3-(4,5-dihydro-3-isoxazolyl)-2-methyl-4-(methylsulfonyl)phenyl](5-hydroxy-1-nethyl-1Hpyrazol-4-yl)methanone\}.
\end{abstract}

The six primary carotenoids found in most plant species include zeaxanthin, antheraxanthin, violaxanthin, lutein, $\beta$-carotene, and neoxanthin (Sandmann, 2001). Carotenoids are pigments integrated into light-harvesting complexes of chloroplasts that function as photoprotectants; carotenoids quench free radicals, perform non-photochemical quenching, and dissipate excess heat and light energy (Croce et al., 1999; Demmig-Adams et al., 1996; Frank and Cogdell, 1996). Carotenoids can

Received for publication 2 July 2010. Accepted for publication 29 Sept. 2010.

${ }^{1}$ To whom reprint requests should be addressed; e-mail jbrosnan@utk.edu. violaxanthin) (Buchanan et al., 2000; DemmigAdams et al., 1996).

Mesotrione, topramezone, and tembotrione are herbicides that affect carotenoid biosynthesis by inhibiting HPPD (EC 1.13.11.27), a precursor to plastoquinone and tocopherols (Bollman et al., 2008; Grossman and Ehrhardt, 2007; Mitchell et al., 2001; Pallett et al., 1998; Secor, 1994). Inhibition of HPPD prevents the formation of plastoquinone, a cofactor required for phytoene desaturase to convert phytoene to phytofluene to $\zeta$-carotene and successive carotenoids (Buchanan et al., 2000). Tissue bleaching (i.e., whitening) that occurs after mesotrione, tembotrione, and topramezone application is attributed to a decrease in carotenoid production from reduced phytoene desaturase activity. The lack of tocopherols also contributes to plant death through a decrease in buffering capacity to reactive oxygen species (Matringe et al., 2005).

Topramezone and tembotrione are currently registered for use in corn (Zea mays L.) (Anonymous, 2006, 2009a; Bollman et al., 2008) and are being evaluated for weed control efficacy in turfgrass and ornamentals (Armel et al., 2009; Brosnan et al., 2010). Mesotrione is currently registered for weed control in turf (Anonymous, 2009b) and has been shown to injure common bermudagrass [Cynodon dactylon (L.) Pers.]. McCurdy et al. (2008) and Willis et al. (2007) reported bermudagrass injury with mesotrione ranging from $9 \%$ to $44 \%$; however, this injury did not result in plant mortality in either study. Bermudagrass injury after treatment with topramezone and tembotrione has not been described in detail.

Data describing the physiological effects of treating common bermudagrass with several rates of mesotrione, topramezone, and tembotrione are limited. Understanding carotenoid fluctuations after applications of mesotrione, topramezone, and tembotrione may provide valuable insight into improving bermudagrass control strategies with these herbicides. Thus, the objective of this study was to evaluate changes in common bermudagrass carotenoid pigments after treatment with mesotrione, topramezone, and tembotrione.

\section{Materials and Methods}

Plant culture. The study was conducted in a greenhouse at the University of TennesseeKnoxville between Aug. and Sept. 2009. Daytime air temperatures in the greenhouse averaged $29.5^{\circ} \mathrm{C}$.

Cores $(6 \mathrm{~cm}$ diameter, $5 \mathrm{~cm}$ depth) of 'Riviera' common bermudagrass were harvested from the East Tennessee Research and Education Center, Knoxville, TN, and transplanted into $10-\mathrm{cm}$ diameter pots filled with a peatmoss $(55 \%)$, perlite $(25 \%)$, and vermiculite $(20 \%)$ growing medium (Super Fine Germinating Mix; Conrad Fafard Inc., Agawam, MA). After transplanting, plants were fertilized with a complete fertilizer biweekly (20 N:20 $\mathrm{P}_{2} \mathrm{O}_{5}: 20 \quad \mathrm{~K}_{2} \mathrm{O}$; Howard Johnson's Triple Twenty Plus Minors, Milwaukee, WI) at $5.2 \mathrm{~kg}$ nitrogen $/$ ha and watered as needed with overhead irrigation to maintain adequate 
soil moisture. Hand shears were used to clip plants three times per week to a height of $2 \mathrm{~cm}$. Plants were allowed to resume active growth for 3 weeks before study initiation.

Herbicide treatments. Plants were treated with mesotrione (Tenacity ${ }^{\circledR}$; Syngenta Professional Products, Greensboro, NC), topramezone (Impact ${ }^{\circledR}$; Amvac Chemical, Los Angeles, CA), and tembotrione (Laudis ${ }^{\circledR}$; Bayer CropScience, Research Triangle Park, NC) at low, medium, and high application rates. Low, medium, and high rates for mesotrione were $0.28,0.35$, and $0.42 \mathrm{~kg} \cdot \mathrm{ha}^{-1}$, respectively. For topramezone, low, medium, and high rates were $0.018,0.025$, and 0.038 $\mathrm{kg} \cdot \mathrm{ha}^{-1}$, respectively. Low, medium, and high rates for tembotrione were $0.092,0.184$, and $0.276 \mathrm{~kg} \cdot \mathrm{ha}^{-1}$, respectively. Low rates represented the maximum labeled use rate for a single application of each herbicide (Anonymous, 2006, 2009a, 2009b). A non-treated control was also included for comparison. All herbicides were mixed with a methylated seed oil surfactant (MSO; Loveland Industries, Greeley, CO) at $0.25 \% \mathrm{v} / \mathrm{v}$, because researchers have reported that MSO increases the herbicidal activity of mesotrione, topramezone, and tembotrione more than nonionic surfactants or crop oil concentrates (Young et al., 2007). Treatments were applied using a $\mathrm{CO}_{2}$-powered boom sprayer containing four flat-fan nozzles (TeeJet 8002 flat fan spray nozzle; Spraying Systems Co., Roswell, GA) calibrated to deliver $280 \mathrm{~L} \cdot \mathrm{ha}^{-1}$ of spray volume. Nozzles were spaced $25 \mathrm{~cm}$ apart and maintained $25 \mathrm{~cm}$ above the surface while spraying. Before treatment application, plants were clipped for the last time at 2-cm height. Leaf material above $2 \mathrm{~cm}$ was harvested from individual plants 3, 7, 14, 21, 28, and 35 DAA. Both treated and non-treated plants were harvested at these intervals.

Data collection. Bermudagrass tissue bleaching was assessed on each sampling date before harvest. Tissue bleaching was visually rated for each whole plant on a $0 \%$ to $100 \%$ scale, in which 0 equaled completely green leaf tissue and 100 equaled completely white leaf tissue. Tissue bleaching was assessed visually because Yelverton et al. (2009) reported that visual ratings of herbicide responses in turf were highly correlated with those measured using the line intersect method or digital image analysis.

On each harvest date, clippings were immediately frozen in liquid nitrogen $(\mathrm{N})$ and placed on ice for transfer to storage at $-80^{\circ} \mathrm{C}$. Tissue pigments were extracted and quantified according to previously published methods (Emenhiser et al., 1996; Kopsell et al., 2007). All clippings were first homogenized in liquid $\mathrm{N}$ using a mortar and pestle. $\mathrm{A} \approx 0.25$-g subsample was placed into a Potter-Elvehjem tissue grinder tube (Kontes, Vineland, NJ) with $2.5 \mathrm{~mL}$ of tetrahydrofuran (THF). Extraction efficiency was measured through the addition of $0.8 \mathrm{~mL}$ of ethyl- $\beta$-apo- 8 ' -carotenoate (Sigma Chemical Co., St. Louis, MO) to selected samples. Recovery of the external standard averaged $72 \%$. Each sample was vortexed and homogenized in the tube using $\approx 25$ insertions with a Potter-Elvehjem tissue grinder pestle attached to a drill press set at $540 \mathrm{rpm}$ while the tube was immersed in ice to dissipate heat. The tube was then placed into a centrifuge for $5 \mathrm{~min}$ at $500 \mathrm{~g}_{\mathrm{n}}$. Precautions were taken to keep the tissue samples on ice during extraction to decrease degradation and increase percent recovery (Kimura and RodriguezAmaya, 1999). The supernatant was removed with a Pasteur pipette, placed into a conical $15-\mathrm{mL}$ test tube, capped, and held on ice during the remainder of the extraction. The sample pellet was resuspended in $2 \mathrm{~mL}$ THF and the extraction procedure was repeated. By the third or fourth extraction, the supernatant was colorless and one additional extraction was conducted. The remaining sample pellet was discarded and the combined supernatants were reduced to $0.5 \mathrm{~mL}$ under $\mathrm{N}$ stream (N-EVAP 111; Organomation Inc., Berlin, MA). Each sample was brought up to a $5-\mathrm{mL}$ volume with acetone. Samples were vortexed and filtered through a $0.2-\mu \mathrm{m}$ polytetrafluoroethylene filter (Econofilter PTFE 25/20; Agilent Technologies, Wilmington, DE) before high-performance liquid chromatography (HPLC) analysis.

HPLC pigment separation and quantification were carried out using an Agilent 1200 series HPLC unit with a photodiode array detector (Agilent Technologies, Palo Alto, CA). The column used was a $250 \times 4.6 \mathrm{~mm}$ i.d., 5- $\mu \mathrm{m}$ analytical scale polymeric $\mathrm{RP}-\mathrm{C}_{30}$ with a $10 \times 4.0-\mathrm{mm}$ i.d. guard cartridge and holder (ProntoSIL; MAC-MOD Analytical Inc., Chadds Ford, PA), which allowed for effective separation of chemically similar carotenoid compounds. The column was maintained at $30{ }^{\circ} \mathrm{C}$ using a thermostatted column compartment. All separations were achieved isocratically using a binary mobile phase of $11 \%$ methyl tert-butyl ether, $88.99 \% \mathrm{MeOH}$, and $0.01 \%$ triethylamine $(\mathrm{v} / \mathrm{v} / \mathrm{v})$. The flow rate was $1.0 \mathrm{~mL} \cdot \mathrm{min}^{-1}$ with a run time of 53 min followed by a 2-min equilibration before the next injection. Eluted compounds from a $10-\mu \mathrm{L}$ injection loop were detected at 453 $\mathrm{nm}$ (carotenoids, chlorophyll $b$, internal standard), and $652 \mathrm{~nm}$ (chlorophyll $a$ ) and data were collected, recorded, and integrated using ChemStation Software (Agilent Technologies) (Demmig-Adams et al., 1996; Frank and Cogdell, 1996). Carotenoids evaluated included: $\beta$-carotene, antheraxanthin, lutein, neoxanthin, violaxanthin, and zeaxanthin. These carotenoids were selected based on their active roles in photoprotection and light harvesting. Peak assignments were performed by comparing retention times to internal standards and line spectra (250 to $700 \mathrm{~nm}$ ) obtained from photodiode array detection with authentic standards (ChromaDex Inc., Irvine, CA). Concentrations of the authentic standards were determined spectrophotometrically using quantitative spectroscopic data (Table 1; Davies and Köst, 1988). Pigments were expressed as $\mathrm{mg} / 100 \mathrm{~g}$ fresh weight (FW) of bermudagrass leaf blade tissue.

Table 1. 'Riviera' bermudagrass (Cynodon dactylon) tissue pigments selected for quantification, including their common and IUPAC chemical names, and information used for calibration of authentic internal standards. ${ }^{\mathrm{z}}$

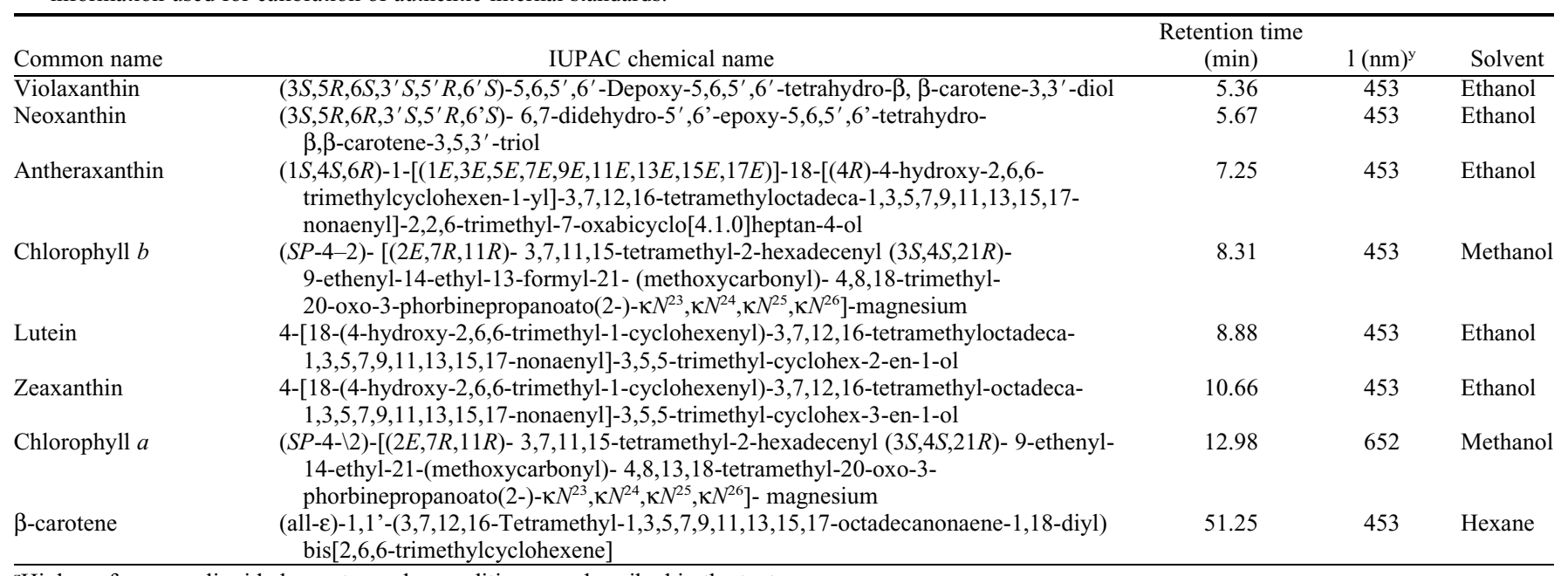

${ }^{\mathrm{z} H i g h-p e r f o r m a n c e ~ l i q u i d ~ c h r o m a t o g r a p h y ~ c o n d i t i o n s ~ a r e ~ d e s c r i b e d ~ i n ~ t h e ~ t e x t . ~}$

${ }^{y}$ Absorbance wavelength for pigment quantification. 
Statistical analysis. Two experimental runs were conducted with treatments in each arranged as a $3 \times 3$ factorial randomized complete block design with three replications. Factors included herbicide (mesotrione, topramezone, and tembotrione) and rate (low, medium, and high). Data from non-treated plants were excluded from statistical analysis to stabilize variance (Corbett et al., 2004); additionally, square-root transformations were also performed before subjecting data to analysis of variance $(P=0.05$; Statistical Analysis Software, Inc., Cary, NC) (Ahrens et al., 1990). Interpretations were not different from nontransformed data; therefore, non-transformed means are presented here for clarity. Fisher's protected least significant difference test $(P=$ 0.05 ) was used to separate treatment means where appropriate. No significant herbicideby-rate interactions were detected in bermudagrass carotenoid pigment data. Thus, changes in tissue pigments resulting from herbicide (pooled across rates) are plotted over harvest interval with SE bars presented as a means of statistical comparison. Trend analyses $(P=$ 0.05 ) were conducted using orthogonal polynomial contrasts to model significant changes in tissue pigments as a result of application rate as well.

\section{Results and Discussion}

Visual bleaching. Significant herbicideby-rate interactions were detected in visual bleaching data. Visual bleaching increased linearly with mesotrione rate at 7 and 14 DAA (Table 2). For mesotrione, the highest level of bleaching occurred at 7 DAA $(22 \%)$ with the highest rate tested $\left(0.42 \mathrm{~kg} \cdot \mathrm{ha}^{-1}\right)$ (Table 2). Bleaching never exceeded $10 \%$ after treatment with the maximum labeled use rate of mesotrione $\left(0.28 \mathrm{~kg} \cdot \mathrm{ha}^{-1}\right)$ (Table 2). No differences in bleaching were detected between mesotrione rates after 14 DAA, and by 28 DAA, no visual bleaching was observed for any mesotrione treatment (Table 2). Similar responses have been reported by other researchers investigating bermudagrass bleaching after mesotrione treatment (McCurdy et al., 2008; Willis et al., 2007).

With the exception of 7 DAA, no significant differences were detected between topramezone rates until 28 DAA (Table 2). All rates resulted in greater than $50 \%$ visual bleaching at 14 DAA compared with only $19 \%$ bleaching for the highest $\left(0.42 \mathrm{~kg} \cdot \mathrm{ha}^{-1}\right)$ rate of mesotrione (Table 2). Visual bleaching decreased for all topramezone rates after 21 DAA (Table 2). Once visual bleaching began to subside, a linear response was detected among rates with the high $\left(0.038 \mathrm{~kg} \cdot \mathrm{ha}^{-1}\right)$ rate producing more bleaching than the medium $\left(0.025 \mathrm{~kg} \cdot \mathrm{ha}^{-1}\right)$ and low $\left(0.018 \mathrm{~kg} \cdot \mathrm{ha}^{-1}\right)$ rates (Table 2).

Bleaching responses for tembotrione were similar to topramezone. No differences were detected between tembotrione rates until 21 DAA (Table 2). All rates resulted in greater than $32 \%$ visual bleaching at 14 DAA, compared with greater than $50 \%$ for all rates of topramezone and only $19 \%$ bleaching for
Table 2. Effect of herbicide-by-rate interaction on visual bleaching of 'Riviera' bermudagrass treated with mesotrione, topramezone, and tembotrione.

\begin{tabular}{|c|c|c|c|c|c|c|c|}
\hline \multirow[b]{2}{*}{ Herbicide } & \multirow[b]{2}{*}{ Rate } & \multicolumn{6}{|c|}{ Visual bleaching (\%) } \\
\hline & & $3 \mathrm{DAA}$ & 7 DAA & 14 DAA & $21 \mathrm{DAA}$ & $28 \mathrm{DAA}$ & $35 \mathrm{DAA}$ \\
\hline \multirow[t]{3}{*}{ Mesotrione } & Low $\left(0.28 \mathrm{~kg} \cdot \mathrm{ha}^{-1}\right)$ & 2 & 9 & 4 & 1 & 0 & 0 \\
\hline & $\operatorname{Med}\left(0.35 \mathrm{~kg} \cdot \mathrm{ha}^{-1}\right)$ & 4 & 19 & 14 & 3 & 0 & 0 \\
\hline & $\operatorname{High}\left(0.42 \mathrm{~kg} \cdot \mathrm{ha}^{-1}\right)$ & 4 & 22 & 19 & 5 & 0 & 0 \\
\hline Linear $_{0.05}$ & & $\mathrm{NS}^{\mathrm{z}}$ & $* \mathrm{y}$ & * & NS & NS & NS \\
\hline Quadratic $_{0.05}$ & & NS & NS & NS & NS & NS & NS \\
\hline \multirow[t]{3}{*}{ Topramezone } & Low $\left(0.018 \mathrm{~kg} \cdot \mathrm{ha}^{-1}\right)$ & 6 & 32 & 57 & 46 & 13 & 4 \\
\hline & $\operatorname{Med}\left(0.025 \mathrm{~kg} \cdot \mathrm{ha}^{-1}\right)$ & 5 & 25 & 57 & 48 & 11 & 3 \\
\hline & $\operatorname{High}\left(0.038 \mathrm{~kg} \cdot \mathrm{ha}^{-1}\right)$ & 3 & 28 & 50 & 58 & 27 & 14 \\
\hline Linear $_{0.05}$ & & NS & $*$ & NS & NS & * & $* *$ \\
\hline Quadratic $_{0.05}$ & & NS & NS & NS & NS & NS & $*$ \\
\hline \multirow[t]{3}{*}{ Tembotrione } & Low $\left(0.092 \mathrm{~kg} \cdot \mathrm{ha}^{-1}\right)$ & 5 & 26 & 33 & 15 & 6 & 1 \\
\hline & $\operatorname{Med}\left(0.184 \mathrm{~kg} \cdot \mathrm{ha}^{-1}\right)$ & 2 & 19 & 41 & 34 & 11 & 2 \\
\hline & $\operatorname{High}\left(0.276 \mathrm{~kg} \cdot \mathrm{ha}^{-1}\right)$ & 3 & 28 & 45 & 58 & 36 & 22 \\
\hline Linear $_{0.05}$ & & NS & NS & NS & $* * *$ & $* * *$ & $* *$ \\
\hline Quadratic $_{0.05}$ & & NS & NS & NS & NS & NS & NS \\
\hline
\end{tabular}

$\mathrm{z}_{\mathrm{NS}}=$ non-significant at the $\alpha=0.05$ level.

y*,**,*** $=$ significant at the $P \leq 0.05,0.01$, and 0.001 levels, respectively.

DAA $=$ days after application.

Table 3. Effect of herbicide-by-rate interaction on total chlorophyll (chlorophyll a + chlorophyll b) concentration $[\mathrm{mg} / 100 \mathrm{~g}$ fresh weight $(\mathrm{FW})]$ of 'Riviera' bermudagrass treated with mesotrione, topramezone, and tembotrione.

\begin{tabular}{|c|c|c|c|c|c|c|c|}
\hline \multirow[b]{2}{*}{ Herbicide } & \multirow[b]{2}{*}{ Rate } & \multicolumn{6}{|c|}{ Total chlorophyll ${ }^{\mathrm{z}}(\mathrm{mg} / 100 \mathrm{~g} \mathrm{FW})$} \\
\hline & & $3 \mathrm{DAA}$ & $7 \mathrm{DAA}$ & 14 DAA & 21 DAA & 28 DAA & $35 \mathrm{DAA}$ \\
\hline \multirow[t]{3}{*}{ Mesotrione } & Low $\left(0.28 \mathrm{~kg} \cdot \mathrm{ha}^{-1}\right)$ & 249.6 & 145.3 & 214.5 & 211.4 & 247.9 & 237.6 \\
\hline & Med $\left(0.35 \mathrm{~kg} \cdot \mathrm{ha}^{-1}\right)$ & 255.3 & 130.3 & 223.6 & 251.3 & 269.4 & 271.6 \\
\hline & $\operatorname{High}\left(0.42 \mathrm{~kg} \cdot \mathrm{ha}^{-1}\right)$ & 241.0 & 107.8 & 179.4 & 217.2 & 276.6 & 274.4 \\
\hline \multirow{2}{*}{\multicolumn{2}{|c|}{$\begin{array}{l}\text { Linear }_{0.05} \\
\text { Quadratic } \\
0.05\end{array}$}} & $\mathrm{NS}^{\mathrm{y}}$ & NS & NS & NS & NS & NS \\
\hline & & NS & NS & NS & NS & NS & NS \\
\hline \multirow[t]{3}{*}{ Topramezone } & Low $\left(0.018 \mathrm{~kg} \cdot \mathrm{ha}^{-1}\right)$ & 226.7 & 94.2 & 85.4 & 158.9 & 255.9 & 276.8 \\
\hline & Med $\left(0.025 \mathrm{~kg} \cdot \mathrm{ha}^{-1}\right)$ & 223.5 & 72.0 & 90.8 & 159.3 & 255.7 & 300.8 \\
\hline & High $\left(0.038 \mathrm{~kg} \cdot \mathrm{ha}^{-1}\right)$ & 213.8 & 83.6 & 45.3 & 98.4 & 206.7 & 269.9 \\
\hline \multirow{2}{*}{\multicolumn{2}{|c|}{$\begin{array}{l}\text { Linear }_{0.05} \\
\text { Quadratic }_{0.05}\end{array}$}} & NS & NS & NS & NS & NS & NS \\
\hline & & NS & NS & NS & NS & NS & NS \\
\hline \multirow[t]{3}{*}{ Tembotrione } & Low $\left(0.092 \mathrm{~kg} \cdot \mathrm{ha}^{-1}\right)$ & 247.2 & 97.3 & 149.9 & 206.3 & 261.4 & 288.1 \\
\hline & Med $\left(0.184 \mathrm{~kg} \cdot \mathrm{ha}^{-1}\right)$ & 226.4 & 89.0 & 76.2 & 145.8 & 249.7 & 280.8 \\
\hline & High $\left(0.276 \mathrm{~kg} \cdot \mathrm{ha}^{-1}\right)$ & 213.8 & 80.8 & 64.7 & 114.6 & 206.7 & 254.3 \\
\hline Linear $_{0.05}$ & & NS & $* * \mathrm{x}$ & NS & NS & NS & NS \\
\hline Quadratic $_{0.05}$ & & NS & NS & * & NS & NS & NS \\
\hline
\end{tabular}

${ }^{{ }^{2}}$ Total chlorophyll concentrations in non-treated plants measured 238.2, 192.9, 214.4, 195.0, 238.9, and $241.1 \mathrm{mg} / 100 \mathrm{~g} \mathrm{FW}$ at $3,7,14,21,28$, and 35 DAA, respectively.

$\mathrm{y}_{\mathrm{NS}}=$ non-significant at the $\alpha=0.05$ level.

x*, **, = significant at the $P \leq 0.01$ and 0.001 levels, respectively.

DAA $=$ days after application.

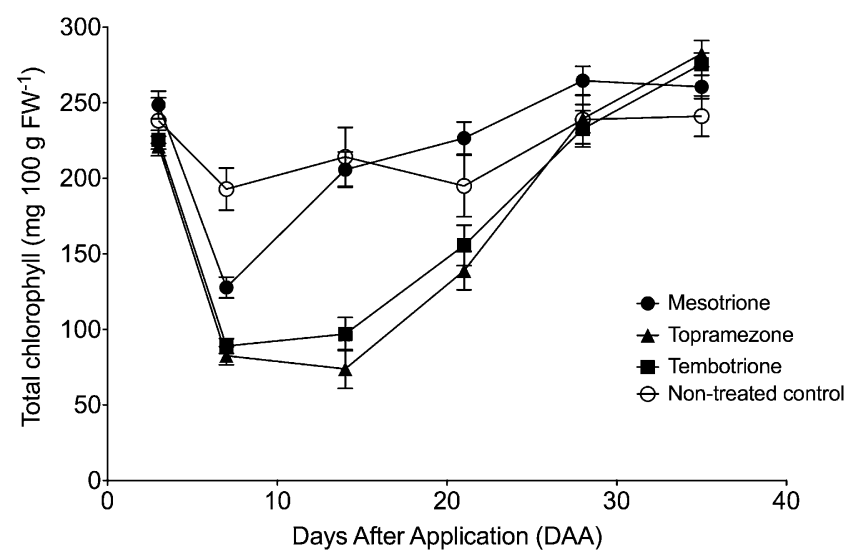

Fig. 1. Total chlorophyll (chlorophyll $a$ and $b$ ) concentration [mg/100 g fresh weight (FW)] in 'Riviera' bermudagrass [Cynodon dactylon (L.) Pers.] treated with mesotrione, topramezone, and tembotrione at $3,7,14,21,28$, and $35 \mathrm{~d}$ after application. Error bars indicate sEs. 
the high $\left(0.42 \mathrm{~kg} \cdot \mathrm{ha}^{-1}\right)$ rate of mesotrione (Table 2). Similar to topramezone, visual tissue bleaching began to subside at 21 DAA. Once bleaching began to subside, linear responses were detected among tembotrione rates suggesting that single applications at higher rates may improve activity against bermudagrass (Table 2).

Chlorophyll. Few statistically significant differences were detected among the low, medium, and high application rates of mesotrione, topramezone, and tembotrione (Table $3)$. Increases in bleaching at 7 DAA were accompanied by reductions in the concentration of total chlorophyll for all herbicides (Fig. 1). At 7 DAA, total chlorophyll for mesotrione-treated plants measured $127.8 \mathrm{mg} /$ $100 \mathrm{~g}$ FW compared with $192.9 \mathrm{mg} / 100 \mathrm{~g} \mathrm{FW}$ for the non-treated control. By 14 DAA, concentrations of total chlorophyll for meso- trione- and non-treated plants were not significantly different. Topramezone and tembotrione reduced total chlorophyll to a greater extent than mesotrione at 7 DAA and did not rebound to non-treated levels until 28 DAA (Fig. 1).

Lutein and $\beta$-carotene. Changes in total carotenoids resulting from herbicide treatment are most likely related to the rise and fall of lutein and $\beta$-carotene, because these pigments comprised greater than $53 \%$ of the total carotenoids measured on each harvest date. At 7 DAA, topramezone- $(5.3 \mathrm{mg} / 100 \mathrm{~g} \mathrm{FW})$ and tembotrione- $(5.5 \mathrm{mg} / 100 \mathrm{~g} \mathrm{FW})$ treated plants measured lower in lutein than those treated with mesotrione (7.7 mg/100 g FW) (Fig. 2). By 14 DAA, mesotrione- and non-treated plants had equivalent lutein concentrations; topramezone- and tembotrione-treated plants were not equivalent to the non-treated controls until 28 and 35 DAA, respectively.
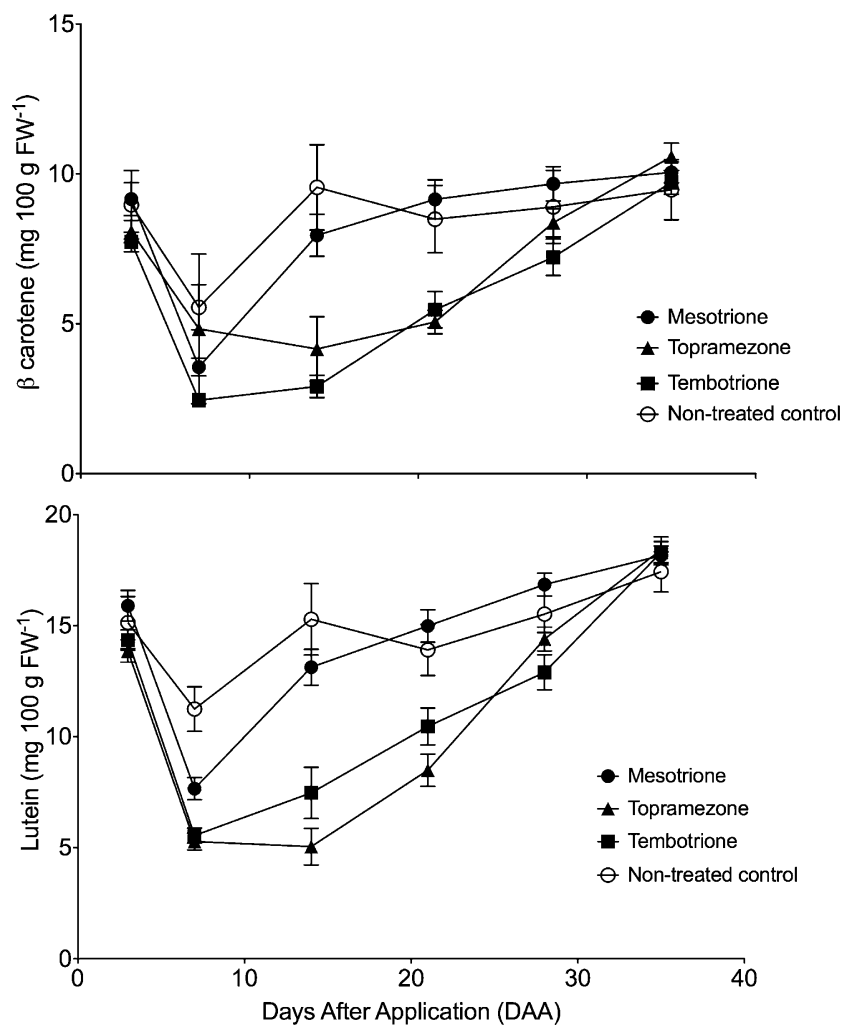

Fig. 2. Leaf blade lutein and $\beta$-carotene $[\mathrm{mg} / 100 \mathrm{~g}$ fresh weight (FW)] in 'Riviera' bermudagrass [Cynodon dactylon (L.) Pers.] treated with mesotrione, topramezone, tembotrione, or non-treated at 3 , 7, 14, 21, 28, and $35 \mathrm{~d}$ after application. Error bars indicate sEs.

Topramezone affected lutein to a greater extent than tembotrione; topramezone reduced lutein $67 \%$ (compared with the non-treated control) at 14 DAA, whereas tembotrione only led to a $51 \%$ reduction. A similar response was observed 21 DAA as well (Fig. 2).

Reductions in $\beta$-carotene were greater for tembotrione than mesotrione. Compared with the non-treated control $(5.5 \mathrm{mg} / 100 \mathrm{~g} \mathrm{FW})$, tembotrione led to a $56 \%$ reduction in $\beta$-carotene $(2.4 \mathrm{mg} / 100 \mathrm{~g} \mathrm{FW})$, whereas mesotrione only led to a $35 \%$ reduction $(3.6 \mathrm{mg}$ / $100 \mathrm{~g} \mathrm{FW}$ ) at 7 DAA (Fig. 2). $\beta$-carotene levels for mesotrione-treated plants were not different from non-treated controls after 7 DAA (Fig. 2). No differences in $\beta$-carotene were detected between tembotrione- and topramezone-treated plants on each harvest date.

At the point of maximum visual bleaching (14 DAT), linear reductions in lutein were observed among the low, medium, and high rates of each herbicide (Table 4); lutein concentrations after treatment at low and medium rates measured $9.7 \mathrm{mg} / 100 \mathrm{~g} \mathrm{FW}$ compared with $6.3 \mathrm{mg} / 100 \mathrm{~g} \mathrm{FW}$ after treatment at high rates (Table 4). Comparatively, the lutein concentration of non-treated plants at 14 DAA measured $15.3 \mathrm{mg} / 100 \mathrm{~g}$ FW (Table 4). Linear reductions in $\beta$-carotene were also observed among the low, medium, and high application rates by 21 DAA (Table 4$)$.

Xanthophyll cycle pigments. Xanthophyll cycle pigments (zeaxanthin + antheraxanthin + violaxanthin) participate as antioxidants in light-harvesting complexes (Demmig-Adams et al., 1996; Niyogi et al., 1997). Mesotrione, topramezone, and tembotrione lowered the concentration of total xanthophyll cycle pigments compared with the non-treated control at 7 DAA (Fig. 3). Concentrations of total xanthophyll cycle pigments for mesotrione and non-treated controls were equivalent at 14 DAA, whereas topramezone- and tembotrione-treated plants were not equivalent to the non-treated controls until 28 and 21 DAA, respectively (Fig. 3).

After peak visual bleaching occurred (14 DAA), topramezone and tembotrione appeared to affect xanthophyll cycle function, because the percentage of zeaxanthin + antheraxanthin in the total xanthophyll pigment pool (ZA/ ZAV) increased in topramezone- and tembotrione-treated plants from 14 to 21 DAA (Fig. 3). Pooled across all herbicides, ZA/ZAV increased linearly with application rate as

Table 4. Effects of application rate (pooled across herbicide) on lutein and $\beta$-carotene concentrations [mg/100 $\mathrm{g}$ fresh weight (FW)] in 'Riviera' bermudagrass leaf tissues $3,7,14,21,28$, and $35 \mathrm{~d}$ after treatment with mesotrione, topramezone, and tembotrione.

\begin{tabular}{|c|c|c|c|c|c|c|c|c|c|c|c|c|}
\hline \multirow[b]{2}{*}{ Herbicide rate } & \multicolumn{6}{|c|}{ Lutein $\left(\mathrm{mg} / 100 \mathrm{~g} \mathrm{FW}^{\mathrm{z}}\right.$} & \multicolumn{6}{|c|}{$\beta$-carotene $(\mathrm{mg} / 100 \mathrm{~g} \mathrm{FW})^{\mathrm{y}}$} \\
\hline & 3 DAA & 7 DAA & 14 DAA & $21 \mathrm{DAA}$ & 28 DAA & $35 \mathrm{DAA}$ & $3 \mathrm{DAA}$ & $7 \mathrm{DAA}$ & 14 DAA & $21 \mathrm{DAA}$ & $28 \mathrm{DAA}$ & $35 \mathrm{DAA}$ \\
\hline$\overline{\text { Low }}$ & 15.3 & 6.9 & 9.7 & 12.6 & 15.8 & 18.2 & 8.8 & 5.5 & 6.2 & 7.4 & 8.9 & 10.2 \\
\hline Medium & 14.8 & 5.9 & 9.7 & 11.7 & 15.7 & 18.9 & 8.4 & 2.7 & 4.7 & 7.1 & 8.9 & 10.6 \\
\hline High & 14.0 & 5.7 & 6.3 & 9.6 & 13.6 & 17.8 & 7.8 & 2.6 & 4.1 & 5.2 & 7.4 & 9.6 \\
\hline Linear $_{0.05}$ & $\mathrm{NS}^{\mathrm{x}}$ & NS & $* * w$ & $*$ & $* *$ & NS & NS & NS & NS & $* *$ & $*$ & NS \\
\hline Quadratic $_{0.05}$ & NS & NS & NS & $*$ & NS & NS & NS & NS & NS & $*$ & NS & NS \\
\hline
\end{tabular}

${ }^{\mathrm{z}}$ Lutein concentrations in non-treated plants measured 15.1, 11.2, 15.3, 13.9, 15.5, and 17.4 mg/100 g FW at 3, 7, 14, 21, 28, and 35 DAA, respectively.

$\mathrm{y} \beta$-carotene concentrations in non-treated plants measured $8.9,5.5,9.5,8.5,8.9$, and $9.5 \mathrm{mg} / 100 \mathrm{~g} \mathrm{FW}$ at 3,7 , 14, 21, 28, and 35 DAA, respectively.

${ }^{\mathrm{N}} \mathrm{NS}=$ non-significant at the $\alpha=0.05$ level.

w, **, = significant at the $P \leq 0.01$ and 0.001 levels, respectively.

$\mathrm{DAA}=$ days after application. 
well (Table 5). By 21 DAA, reductions in bleaching for all herbicides were accompanied by reductions in ZA/ZAV (Table 2; Fig. 3).

Stress induced by these herbicides from 14 to 21 DAA may have influenced violaxanthin de-epoxidase activity, thus increasing the conversion of violaxanthin to the intermediate antheraxanthin and subsequently zeaxanthin, the primary carotenoid responsible for preventing photoinhibition (Baroli et al., 2003).

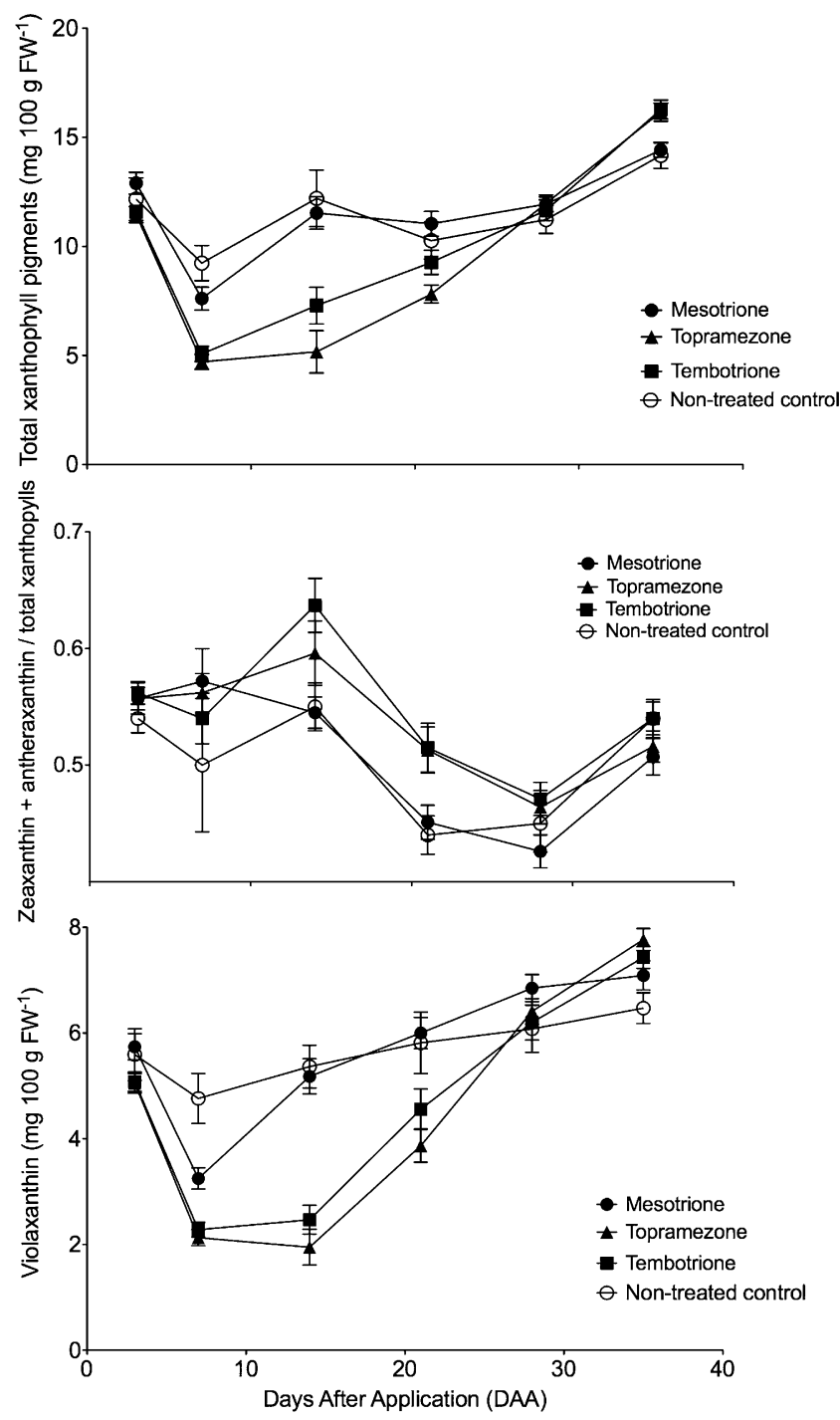

Fig. 3. Leaf blade total xanthophyll (zeaxanthin + antheraxanthin + violaxanthin) concentration, violaxanthin concentration $[\mathrm{mg} / 100 \mathrm{~g}$ fresh weight $(\mathrm{FW})]$, and zeaxanthin + antheraxanthin/total xanthophyll ratio (ZA/ZAV) in 'Riviera' bermudagrass [Cynodon dactylon (L.) Pers.] treated with mesotrione, topramezone, tembotrione, or non-treated at 3, 7, 14, 21, 28, and $35 \mathrm{~d}$ after application. Error bars indicate sEs.

When peak visual bleaching occurred (14 DAT), violaxanthin was reduced by more than $50 \%$ in topramezone- and tembotrionetreated plants and linear reductions in violaxanthin were also detected among application rates (Fig. 3; Table 5). Polle et al. (2001) reported that zeaxanthin can replace violaxanthin and lutein in light-harvesting antennae of photosystem II and photosystem I. Moreover, Depka et al. (1998) reported a conversion of $\beta$-carotene to zeaxanthin under conditions of high light stress and surmised that this conversion was required to maintain the integrity of the D1 protein of photosystem II. On each date that linear increases in ZA/ZAV were observed in the current study, linear reductions in $\beta$-carotene were observed as well (Tables 2 and 3).

\section{Conclusion}

This research outlines several findings. First, temporary cessation of phytoene desaturase activity from mesotrione, topramezone, and tembotrione did not result in equivalent decreases in all carotenoids. Topramezone and tembotrione resulted in greater visual bleaching than mesotrione and consequently greater reductions in total chlorophyll, lutein, $\beta$-carotene, and xanthophyll cycle pigments as well. Considering the roles $\beta$-carotene and the xanthophyll cycle pigments play in photosystem II functionality and non-photochemical quenching, responses in this study suggest topramezone and tembotrione are more herbicidally active against bermudagrass than mesotrione.

Few differences in bleaching were detected between rates of topramezone and tembotrione before 21 DAA. Linear increases in bleaching were reported with increasing rates of mesotrione as soon as 7 DAA. This information supports the concept that topramezone and tembotrione are more active against bermudagrass than mesotrione. Furthermore, current maximum labeled use rates of mesotrione, topramezone, and tembotrione may need to be increased to provide improved herbicidal activity against bermudagrass, because concentrations of most carotenoid pigments decreased linearly with increased application rate.

Third, topramezone and tembotrione increased the percentage of zeaxanthan + antheraxanthin in the total xanthophyll pigment

Table 5. Effects of application rate (pooled across herbicide) on the concentration of violaxanthin $[\mathrm{mg} / 100 \mathrm{~g}$ fresh weight (FW)] and the ratio of zeaxanthin + antheraxanthin to the concentration of total xanthophyll pigments (ZA/ZAV) in 'Riviera' bermudagrass leaf tissues 3, 7, 14, 21, 28, and 35 d after treatment with mesotrione, topramezone, and tembotrione.

\begin{tabular}{|c|c|c|c|c|c|c|c|c|c|c|c|c|}
\hline \multirow[b]{2}{*}{ Herbicide Rate } & \multicolumn{6}{|c|}{ Violaxanthin $(\mathrm{mg} / 100 \mathrm{~g} \mathrm{FW})^{\mathrm{z}}$} & \multicolumn{6}{|c|}{$\mathrm{ZA} / \mathrm{ZAV}^{\mathrm{y}}$} \\
\hline & $3 \mathrm{DAA}$ & $7 \mathrm{DAA}$ & $14 \mathrm{DAA}$ & $21 \mathrm{DAA}$ & 28 DAA & $35 \mathrm{DAA}$ & $3 \mathrm{DAA}$ & 7 DAA & 14 DAA & $21 \mathrm{DAA}$ & 28 DAA & $35 \mathrm{DAA}$ \\
\hline Medium & 5.4 & 2.5 & 3.4 & 5.1 & 6.9 & 7.8 & 0.56 & 0.55 & 0.60 & 0.48 & 0.44 & 0.51 \\
\hline Quadratic $_{0.05}$ & NS & NS & * & NS & NS & NS & NS & NS & NS & NS & NS & NS \\
\hline
\end{tabular}

${ }^{2}$ Violaxanthin concentrations in non-treated plants measured 5.6, 4.8, 5.4, 5.8, 6.1, and $6.5 \mathrm{mg} / 100 \mathrm{~g} \mathrm{FW}$ at 3, 7, 14, 21, 28, and 35 DAA, respectively.

${ }^{\mathrm{y}} \mathrm{ZA} / \mathrm{ZAV}=$ ratio of zeaxanthin + antheraxanthin to the total xanthophyll pigment concentration (zeaxanthin + antheraxanthin + violaxanthin. ZA/ZAV in nontreated plants measured $0.54,0.50,0.55,0.44,0.45$, and 0.54 at $3,7,14,21,28$, and 35 DAA, respectively.

${ }^{\mathrm{x}_{\mathrm{NS}}}=$ non-significant at the $\alpha=0.05$ level.

w* = significant at the $P \leq 0.01$ and 0.001 levels, respectively.

$\mathrm{DAA}=$ days after application. 
pool (ZA/ZAV) $7 \mathrm{~d}$ after peak visual bleaching was observed (14 DAA). ZA/ZAV increased linearly with application rate from 14 to 21 DAA as well. Considering that zeaxanthin + antheraxanthin are vital for energy dissipation of excess absorbed light (Demmig-Adams, 1990), these increases indicate that bermudagrass leaf tissue is still under considerable stress even after visual bleaching begins to subside. After 21 DAA, reductions in ZA/ ZAV were reported for herbicides. Thus, sequential applications of HPPD-inhibiting herbicides for bermudagrass control should be applied on 14- to 21-d intervals, because the stress imposed by these herbicides appears to be greatest 14 to 21 DAA. Additionally, increases in photoprotective xanthophyll cycle pigments (ZA/ZAV) may be a mechanism by which bermudagrass recovers from HPPDinhibiting herbicide injury. These findings will allow turf managers to design physiologically validated bermudagrass control programs with HPPD-inhibiting herbicides. Further research should investigate how responses of the HPPD inhibitors in the current study are affected by application methods, surfactants, bermudagrass growth stage, climatic conditions, or by applying HPPD inhibitors in mixtures with other herbicides, including inhibitors of photosystem II and other graminicides.

\section{Literature Cited}

Ahrens, W.H., D.J. Cox, and G. Budhwar. 1990. Use of the arcsine and square root transformations for subjectively determined percentage data. Weed Sci. 38:452-458.

Anonymous. 2006. Impact herbicide label. 119263. AMVAC, Los Angeles, CA.

Anonymous. 2009a. Laudis herbicide label. Bayer CropScience LP, Research Triangle Park, NC.

Anonymous. 2009b. Tenacity herbicide label. Syngenta Professional Products, Greensboro, NC.

Armel, G.R., W.E. Klingeman, and P.C. Flanagan. 2009. Evaluation of various mixtures of HPPD and PSII inhibitors for weed control in several ornamental plants. Proc. Northeast. Weed Sci. Soc. 63:68.

Baroli, I., A.D. Do, T. Yamane, and K.K. Niyogi. 2003. Zeaxanthin accumulation in the absence of a functional xanthophyll cycle protects Chlamydomonas reinhardtii from photooxidative stress. Plant Cell 15:992-1008.
Bollman, J.D., C.M. Boerboom, R.L. Becker, and V.A. Fritz. 2008. Efficacy and tolerance to HPPD-inhibiting herbicides in sweet corn. Weed Technol. 22:666-674.

Brosnan, J.T., G.R. Armel, W.E. Klingeman, III, G.K. Breeden, J.J. Vargas, and P.C. Flanagan. 2010. Selective Star-of-Bethlehem control with sulfentrazone and mixtures of mesotrione and topramezone with bromoxynil and bentazon in cool-season turfgrass. HortTechnology 20:315318.

Buchanan, B.B., W. Gruissem, and R.L. Jones. 2000. Biochemistry and molecular biology of plants. p. 1159-1160. John Wiley and Sons, Inc., Somerset, NJ.

Corbett, J.L., S.D. Askew, W.E. Thomas, and J.W. Wilcut. 2004. Weed efficacy evaluations for bromoxynil, glufosinate, glyphosate, pyrithiobac, and sulfosate. Weed Technol. 18:443-453.

Croce, R., S. Weiss, and R. Bassi. 1999. Carotenoid-binding sites of the major light-harvesting complex II of higher plants. J. Biol. Chem. 274:29613-29623.

Davies, B.H. and H.P. Köst. 1988. Chromatograhpic methods for the separation of carotenoids, p. 1-185. In: Köst, H.P., G. Zweig, and J. Sherma (eds.). CRC handbook of chromatography, plant pigments: Fat soluble pigments. Vol. 1. CRC Press, Boca Raton, FL.

Demmig-Adams, B. 1990. Carotenoids and photoprotection in plants. A role for the xanthophyll zeaxanthin. Biochim. Biophys. Acta 1020:1-24.

Demmig-Adams, B., A.M. Gilmore, and W.W. Adams, III. 1996. In vivo function of carotenoids in higher plants. FASEB J. 10:403-412.

Depka, B., P. Jahns, and A. Trebst. 1998. $\beta$-carotene to zeaxanthin conversion in the rapid turnover of the D1 protein of photosystem II. FEBS. Let. 424:267-270.

Emenhiser, C., N. Simunovic, L.C. Sander, and S.J. Schwartz. 1996. Separation of geometric carotenoid isomers in biological extracts using a polymeric $\mathrm{C}_{30}$ column in reverse-phase liquid chromatography. J. Agr. Food Chem. 44:38873893.

Frank, H.A. and R.J. Cogdell. 1996. Carotenoids in photosynthesis. Photochem. Photobiol. 63:257264.

Grossman, K. and T. Ehrhardt. 2007. On the mechanism of action and selectivity of the corn herbicide topramezone; a new inhibitor of 4-hydroxyphenylpyruvate dioxygenase. Pest Manag. Sci. 63:429-439.

Kimura, M. and D.B. Rodriguez-Amaya. 1999. Sources of errors in the quantitative analysis of food carotenoids by HPLC. Archivos latinoamericanos de nutricioìn 49:58S-66S.
Kopsell, D.A., T.C. Barickman, C.E. Sams, and J.S. McElroy. 2007. Influence of nitrogen and sulfur on biomass production and carotenoid and glucosinolate concentrations in watercress (Nasturtium officinale R. Br.). J. Agr. Food Chem. 55:10628-10634.

Matringe, M., A. Sailland, B. Pelissier, A. Roland, and O. Zink. 2005. p-hydroxyphenylpyruvate dioxygenase inhibitor-resistant plants. Pest Manag. Sci. 61:269-276.

McCurdy, J.D., J.S. McElroy, G.K. Breeden, and D.A. Kopsell. 2008. Mesotrione plus prodiamine for smooth crabgrass (Digitaria ischaemum) control in established bermudagrass turf. Weed Technol. 22:275-279.

Mitchell, G., D.W. Bartlett, T.E.M. Fraser, T.R. Hawkes, D.C. Holt, J.K. Townson, and R.A. Wichert. 2001. Mesotrione: A new selective herbicide for use in maize. Pest Manag. Sci. 57:120-128.

Niyogi, K.K. 1999. Photoprotection revisited: Genetics and molecular approaches. Annu. Rev. Plant Physiol. Plant Mol. Biol. 50:333-359.

Niyogi, K.K., O. Bjorkman, and A.R. Grossman. 1997. The roles of specific xanthophylls in photoprotection. Proc. Natl. Acad. Sci. USA 94:14162-14167.

Pallett, K.E., J.P. Little, M. Sheekey, and P. Veerasekaran. 1998. The mode of action of isoxaflutole, I. Physiological effects, metabolism, and selectivity. Pestic. Biochem. Physiol. 62:113-124

Polle, J.E.W., K.K. Niyogi, and A. Melis. 2001. Absence of the pigments lutein, violaxanthin, and neoxanthin affects the functional chlorophyll antenna size of photosystem II but not photosystem I in the green alga Chlamydomonas Reinhardtii.. Plant Cell Physiol. 5:482-491.

Sandmann, G. 2001. Genetic manipulation of carotenoid biosynthesis: Strategies, problems and achievements. Trends Plant Sci. 6:14-17.

Secor, J. 1994. Inhibition of barnyardgrass 4hydroxyphenylpyruvate dioxygenase by sulcotrione. Plant Physiol. 106:429-433.

Willis, J.B., S.D. Askew, and J.S. McElroy. 2007. Improved white clover control with mesotrione by tank-mixing bromoxynil, carfentrazone, and simazine. Weed Technol. 21:739-743.

Yelverton, F.H., J.A. Hoyle, T.W. Gannon, and L.S. Warren. 2009. Plant counts, digital image analysis, and visual ratings for estimating weed control in turf: Are they correlated? Proc. South. Weed Sci. Soc. 62:399.

Young, B.G., R.K. Zollinger, and M.L. Bernards. 2007. Variability of tembotrione efficacy as influenced by commercial adjuvant products. Proc. North Central Weed Sci. Soc. 62:141. 